Dept. of Animal Hygiene

Faculty of Veterinary Medicine, Assiut University

\title{
ASESSMENT OF AUTOMATIC AND HAND MILKING SYSTEMS OF COWS IN RELATION TO SOME BEHAVIORAL AND HYGIENIC INDICATIONS OF STRESS
}

(With 4 Tables and 5 Figures)

By

\section{M.A. ABDEL-RAHMAN; MADEHA H.A. DARWISH and S.A. KOTB}

(Received at 20/5/2007)

\section{تقييم نظامى الحلب الآلى واليدوى للأبقار باستخدام بعض الدلالات السلوكية

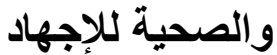

معتز أحد عبل الرحمن ، مديحه حسنى أحدد ، صابر عبل المتجلى قطب

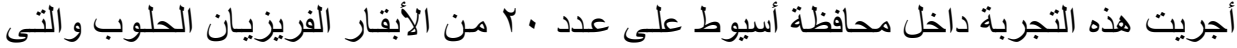

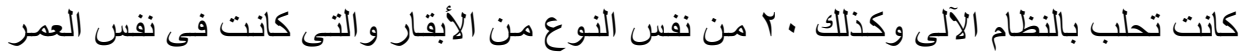

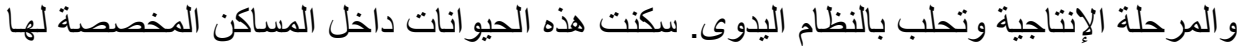

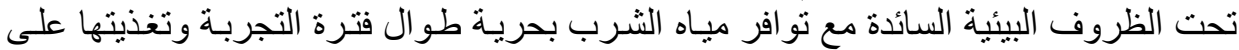

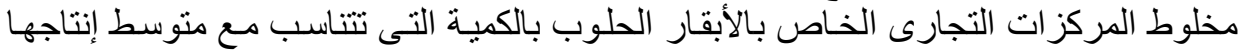

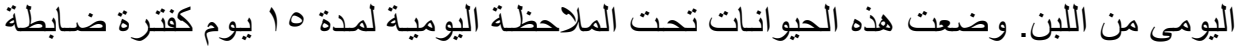

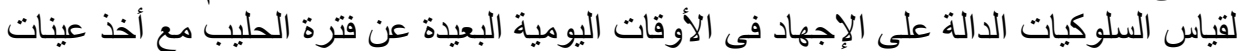

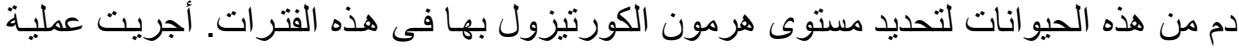

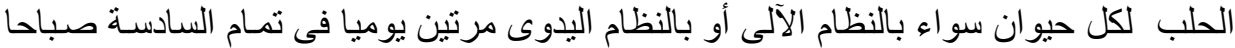

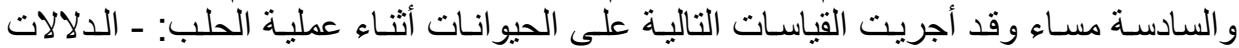

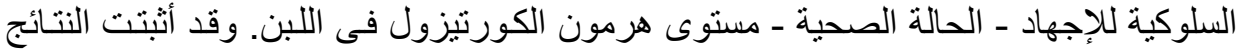

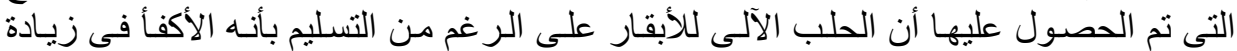

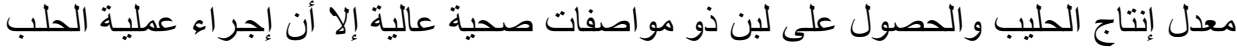

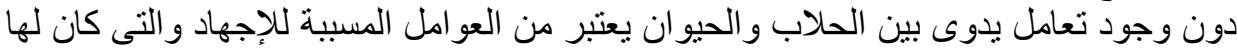

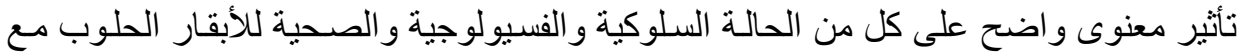

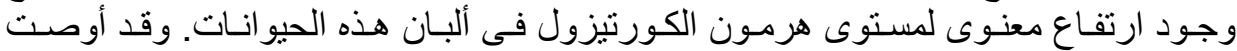

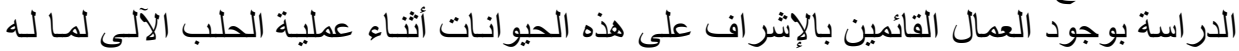

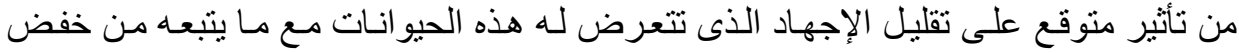
مستوى هرمون الكورتيزول في اللبن. 


\section{SUMMARY}

Twenty multiparous lactating Friesian cows were randomly chosen from a herd of 50 cows milked with an automatic milking system. In addition, another 20 multiparous lactating Friesian cows were randomly chosen from a herd of 50 cows milked with a hand milking system. Each group of cows was housed in a suitable cow byre under the prevalent environmental conditions. Experimented cows of both groups were in their $3^{\text {rd }}$ lactation season. A commercial concentrate mixture for dairy cows was fed to the animals in the milking parlour according to their average milk yield. Barseem was offered to cows in their byres. Animals were allowed free access to the water troughs all the times except during milking where there was no water available in the collecting yards or milking parlour. Cows were milked separately twice a day at 6:00 a.m. and 6:00 p.m., either automatically or handy according to the group. Three parameters were selected to be investigated and measured during this experiment: -Behavioral indicators of stress -Health status -Milk cortisol. The obtained data indicated that, although auto milking is a very important matter in increasing the milk yield and its hygienic state, it seems to indeed affect the behavioral and physiological response as well as health status of cows during milking. Moreover, this study concluded that, human-animal interaction has known positive effects on cortisol level in the sense of stress reduction, where milking without a stockperson, and therefore without any handling procedures, could be more stressful. This finding recommended that, presence of stock persons or workers who managed the dairy cows in their byres during their auto milking is of great importance to minimize stress and so, decrease the level of cortisol in the collected milk.

Key Words: Milking system, behavior, stress, cows.

\section{INTRODUCTION}

In addition to housing and feeding, the milking system is another part of dairy production that has the potential to be automated. Introduction of automatic milking systems could be compared with the revolution in corn harvesting caused by the development of the machines. However, it could have a negative influence on the cow-farmer relationship if all of the cows' basic requirements are freely accessible and they are therefore left alone. 
When justifying the use of fully automatic milking in dairy production, some often mentioned advantages are better time management for farmers as well as better udder health and higher milk yield. (Ipema et al., 1988). However, early studies have shown that cow behavior is affected by the design of the automatic milking systems. (Kremer and Ordolff, 1992) concluded that cows had been suffering from stress due to the novelty of the milking box. Uetake et al. (1997) saw differences in social behavior between conventionally and automatically milked herds. If there are less milking compartments in the automatic system, cows aren't able to react together. Automatic milking systems transfer the decision to the cows of when to be milked (Ketelaar et al., 1996). Automatic milking also seems to restrict cows' behavior because they spend more time standing at the feeding gate and collecting yards (Ketelaar et al., 1998). Moreover, Prescott et al. (1998) found that feeding during milking in an automatic milking system tended to create more shuffling during teat cup attachment, but did not improve cows behavior.

Another important factor to be considered when examining cows' adaptability to the automatic milking system is the stress responses of the cows themselves (Hemsworth et al., 1989, Lay et al., 1992 and Hopster et al., 1998). In a recent study, (Hopster et al., 2000) found significant differences in acute stress responses between automatically and conventionally milked cows.

The aim of the present study was to explore the stress response of cows in both milking systems. Therefore, this study was conducted as an explorative field study under practical conditions in order to investigate behavioral and physiological parameters of cows milked in an automatic milking system as compared to those milked handy in a milking parlor.

\section{MATERIALS and METHODS}

\section{I- Animals used:-}

This experiment was done in a dairy farm at the vicinity of Assiut Governorate, Egypt. Twenty multiparous lactating Friesian cows were randomly chosen from a herd of 50 cows milked with an automatic milking system. In addition, another 20 multiparous lactating Friesian cows were randomly chosen from a herd of 50 cows milked with a hand milking system. Each group of cows was housed in a suitable cow byre under the prevalent environmental conditions. Experimented cows of both groups were in their $3^{\text {rd }}$ lactation season. 


\section{II- Feeding, watering and management:-}

A commercial concentrate mixture for dairy cows was fed to the animals in the milking parlour according to their average milk yield. However, barseem was offered to cows in their byres at a rate of $10 \mathrm{~kg}$ dry matter / cow / day (Little et al., 1979). Mineral salt rocks were hanged freely in front of the animals.

In each byre, water was supplied directly from tap water in a large, well-cleaned concrete water trough, which placed on the ground. Animals were allowed free access to the water troughs all the times except during milking where there was no water available in the collecting yards or milking parlour. Cows were milked separately twice a day at 6:00 a.m. and 6:00 p.m., either automatically or handy according to the group.

\section{III- Data collection:-}

This experiment was carried out during the months of February and March, 2007. Before starting the experiment, experimented animals in both groups were observed inside their byres for a two weeks control period using direct human observation and scan sampling method. Observations were done for two hours directly before their milking for four days / week to determine the behavioral indicators of stress, if present, during out of milking hours. Moreover, blood samples, $10 \mathrm{ml}$ of each, were taken weekly from randomly selected five cows of each group, two hours before their milking time to determine their average serum cortisol level during out of milking time. Samples were centrifuged at 3000 r.p.m for 10 minutes and the obtained sera were stored at $-20^{\circ} \mathrm{C}$ until further analysis to determine its cortisol level using TDxFLx system with fluorescence polarization and competitive binding technique according to Dandliker \& Feigen (1970) and Dandliker \& Saussure (1973).

Moreover, three parameters were selected to be investigated and measured during the experimental period (during milking inside the parlour):-

- Behavioral indicators of stress

- Health status

- Milk cortisol

\section{A- Behavioral indicators of stress: -}

In accordance with Martin and Bateson (1988) as well as Wenzel et al. (2003), behavior of the milked cows was recorded continuously for all of the time that the cows were in the milking stall using direct human observation with focal animal sampling. Observations were separated for 
udder preparation (including udder cleaning and teat cup attachment), main milk flow and final milk flow (the last 2 min of cluster onset). The frequency for both behaviors was calculated. The observed behavioral indicators of stress included the following:-

\section{1- Step behavior:-}

Step behavior is one of the main behavioral indicators of stress that always happened during milking (Wenzel et al., 2003). Step behavior, also called shuffling, was defined as a cow shifting its weight from one hind foot to the other while standing in the milking stall.

\section{2- Kick behavior:-}

Kick behavior is another one of the main behavioral indicators of stress. Kick behavior was defined as a cow lifting its hind foot and moving it forward (Hemsworth et al., 1989, Metz-Stefanowska et al., 1992 and Prescott et al., 1998).

\section{3- Bellowing:-}

Bellowing was defined as a loud vocalization emitted by stressed cattle (Marten and Bateson, 1988). Repeated vocalization by the same cow was considered as one act.

\section{4- Scraping:-}

Scraping was defined as scraping the floor with the claws of the forelimbs of stressed cattle (Marten and Bateson, 1988).

\section{5- Pawing:-}

Pawing was defined by the same authors as rubbing the floor vigorously with the claws of the hind limbs of stressed cattle.

\section{6- Lip licking:-}

It is another indicator of stress. Marten and Bateson (1988) also defined lip licking as repeated and rapid licking of the upper lip (muzzle).

\section{B- Health status:-}

Experimented cows were clinically examined according to Blood \& Henderson (1974) and Blood \& Radostits (1990) to determine their average pulse and respiratory rates. Examination was done according to Wenzel et al. (2003) 10 minutes before entering the milking stall, during milking in the milking stall and 10 minutes after leaving the milking stall.

Moreover, the udder of all cows of both herds, either milked automatically or handy, were investigated continuously to determine the incidence of teat inflammations. Inflamed teat was recognized by redness, hotness and swelling which accompanied with pain (Blood and Radostitis, 1990). 


\section{C- Milk cortisol concentration:-}

A $10 \mathrm{ml}$ milk sample of a randomly selected 5 cows of each group was taken weekly from each cow. Due to the circadian rhythm of cortisol, samples must be taken either during the morning or the afternoon milking (Wenzel et al., 2003). In this study, milk samples were taken during afternoon milking. After collection, milk samples were kept cool and worked up on the same day. Samples were centrifuged at 3000 r.p.m for 10 minutes and the skim milk was stored at $-26^{\circ} \mathrm{C}$ until further analysis to determine its cortisol level using TDxFLx system with fluorescence polarization and competitive binding technique according to Dandliker \& Feigen (1970) and Dandliker \& Saussure (1973).

\section{IV- Statistical analyses:-}

Statistical analyses of the collected data were carried out according to procedures of completely random design, SAS (1995).

\section{RESULTS}

The results of this study were illustrated in Tables $1,2,3,4$ as well as Figures 1, 2, 3, 4 and 5.

Table 1: Behavioral indications of stress inside byres for cows that milked automatically or handy.

\begin{tabular}{lccc}
\hline \multicolumn{1}{c}{ Type of milking } & Automatic & Hand & "P” Value \\
Behavior & 0 & 0 & NS \\
\hline $\begin{array}{l}\text { Step behavior } \\
\text { (No. / head) }\end{array}$ & 0 & 0 & NS \\
\hline $\begin{array}{l}\text { Kick behavior } \\
\text { (No. / head) }\end{array}$ & 5 & 5 & NS \\
\hline $\begin{array}{l}\text { Bellowing } \\
(\% \text { of animals })\end{array}$ & 0 & 0 & NS \\
\hline $\begin{array}{l}\text { Scraping } \\
(\% \text { of animals })\end{array}$ & 0 & 0 & NS \\
\hline $\begin{array}{l}\text { Pawing } \\
(\% \text { of animals })\end{array}$ & 0 & 0 & NS \\
\hline $\begin{array}{l}\text { Lip licking } \\
(\% \text { of animals })\end{array}$ & & & \\
\hline NS = Non-significant & 0 &
\end{tabular}


Table 2: Behavioral indications of stress in cows during automatic and hand milking

\begin{tabular}{|c|c|c|c|c|}
\hline Behavior & milking & Automatic & Hand & "P" Value \\
\hline \multirow{3}{*}{$\begin{array}{l}\text { Step behavior } \\
\text { (No. / head) }\end{array}$} & Udder preparation & $3.4 \pm 0.3$ & $0.6 \pm 0.02$ & $<0.01$ \\
\hline & Main milking & $7.9 \pm 0.6$ & $1.2 \pm 0.1$ & $<0.01$ \\
\hline & Final milking & $4.8 \pm 0.4$ & $0.9 \pm 0.03$ & $<0.01$ \\
\hline \multirow{3}{*}{$\begin{array}{r}\text { Kick behavior } \\
\text { (No. / head) }\end{array}$} & Udder preparation & $1.8 \pm 0.2$ & $0.4 \pm 0.02$ & $<0.01$ \\
\hline & Main milking & $8.1 \pm 0.4$ & $2.2 \pm 0.1$ & $<0.01$ \\
\hline & Final milking & $6.8 \pm 0.3$ & $1.9 \pm 0.3$ & $<0.01$ \\
\hline \multirow{3}{*}{$\begin{array}{c}\text { Bellowing } \\
\text { (\% of animals) }\end{array}$} & Udder preparation & 30 & 5 & $<0.01$ \\
\hline & Main milking & 60 & 10 & $<0.01$ \\
\hline & Final milking & 50 & 5 & $<0.01$ \\
\hline \multirow{3}{*}{$\begin{array}{c}\text { Scraping } \\
\text { (\% of animals) }\end{array}$} & Udder preparation & 20 & 0 & $<0.01$ \\
\hline & Main milking & 30 & 0 & $<0.01$ \\
\hline & Final milking & 30 & 0 & $<0.01$ \\
\hline \multirow{3}{*}{$\begin{array}{c}\text { Pawing } \\
\text { (\% of animals) }\end{array}$} & Udder preparation & 20 & 0 & $<0.01$ \\
\hline & Main milking & 40 & 0 & $<0.01$ \\
\hline & Final milking & 20 & 0 & $<0.01$ \\
\hline \multirow{3}{*}{$\begin{array}{l}\text { Lip licking } \\
\text { (\% of animals) }\end{array}$} & Udder preparation & 10 & 0 & $<0.01$ \\
\hline & Main milking & 40 & 10 & $<0.01$ \\
\hline & Final milking & 30 & 10 & $<0.01$ \\
\hline
\end{tabular}




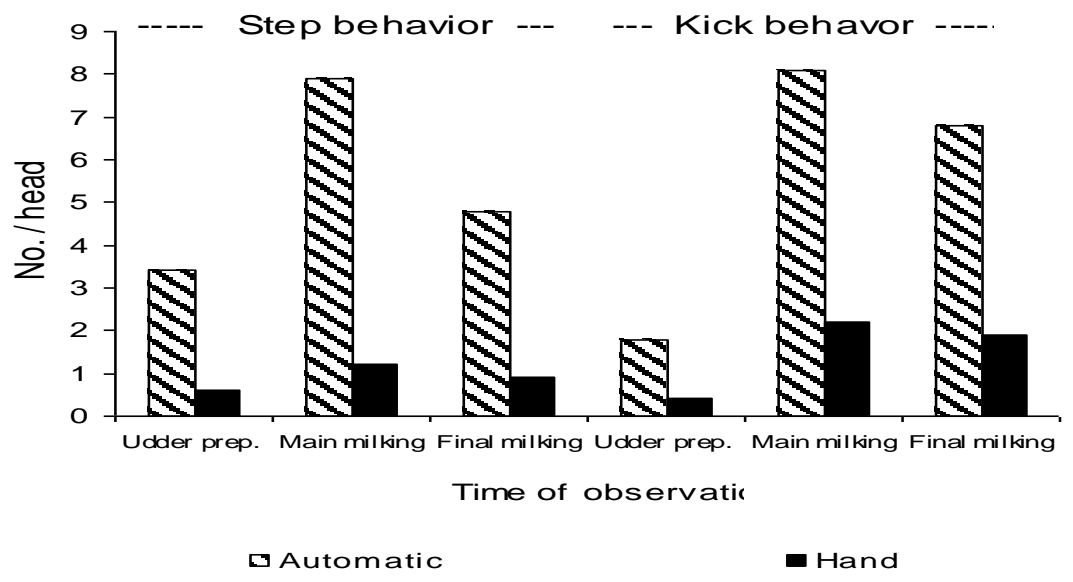

Fig. (1): -Step and kick behavior of cows durins auitom atic and hand milking

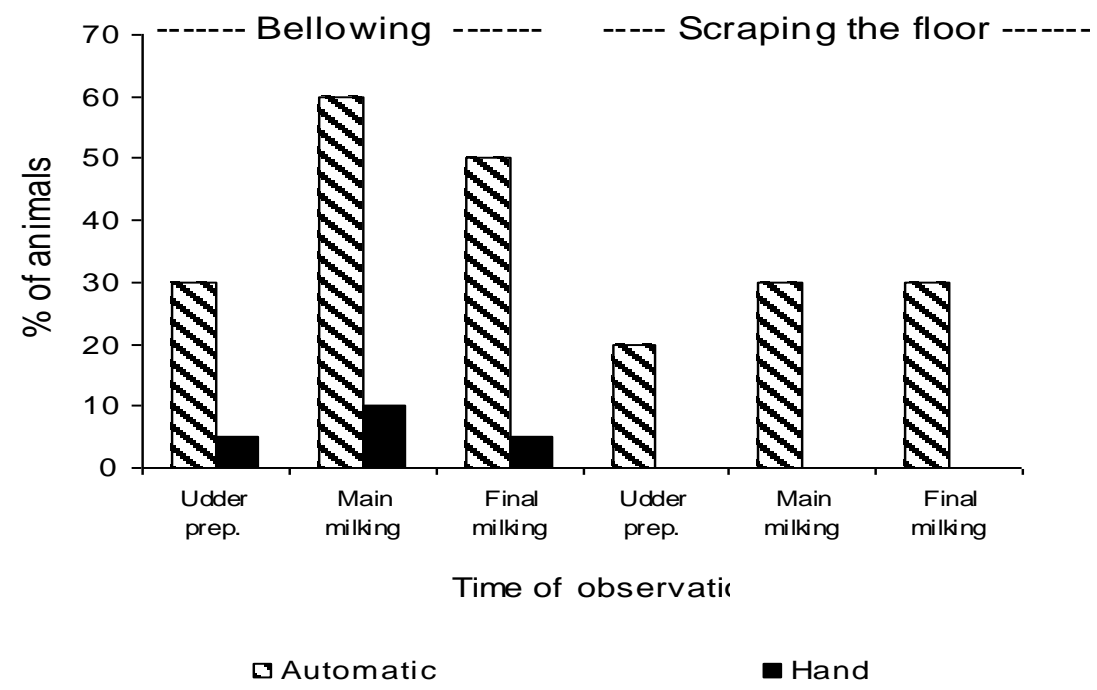

Fig. (2): -Bellowing and scraping the floor with for limbs during auitom atic and hand milking of cov 


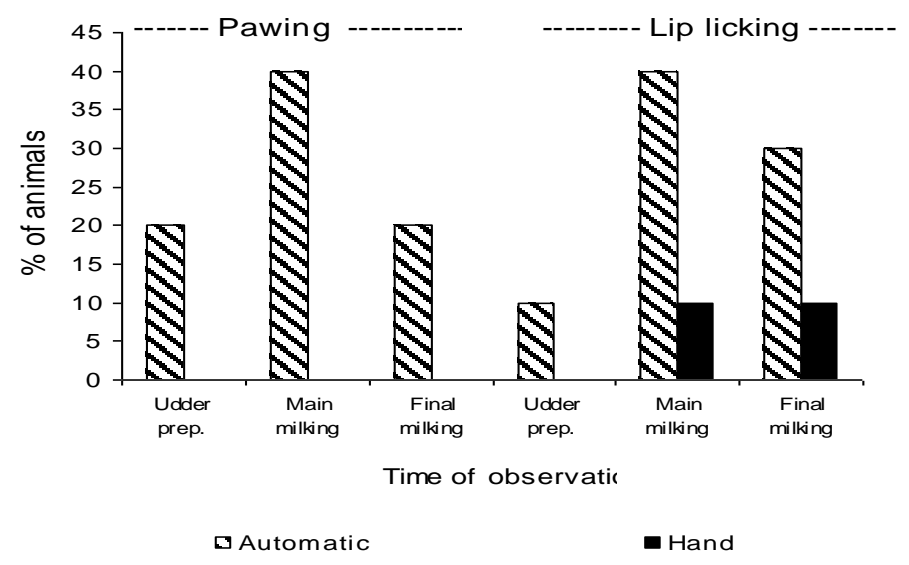

Fig. (3): - Pawing the floor with hind lim bs and lik licking during auitom atic and hand milking of col

Table 3: Health status measurements of cows during automatic and hand milking

\begin{tabular}{lcccc}
\hline \multicolumn{1}{l}{ Type of milking } & & Automatic & Hand & "P" Value \\
\hline & Before & $72 \pm 2$ & $70 \pm 1$ & NS \\
Pulse rate (No./min) & During & $86 \pm 1$ & $72 \pm 1$ & $<0.01$ \\
& After & $74 \pm 1$ & $72 \pm 2$ & NS \\
\hline & Before & $27 \pm 1$ & $26 \pm 1$ & NS \\
Respiratory rate (No./min) & During & $38 \pm 1$ & $27 \pm 1$ & $<0.01$ \\
& After & $29 \pm 1$ & $26 \pm 1$ & NS \\
\hline Teat inflammation (\%) & & 38 & 12 & $<0.01$ \\
\hline
\end{tabular}

NS = Non-significant 


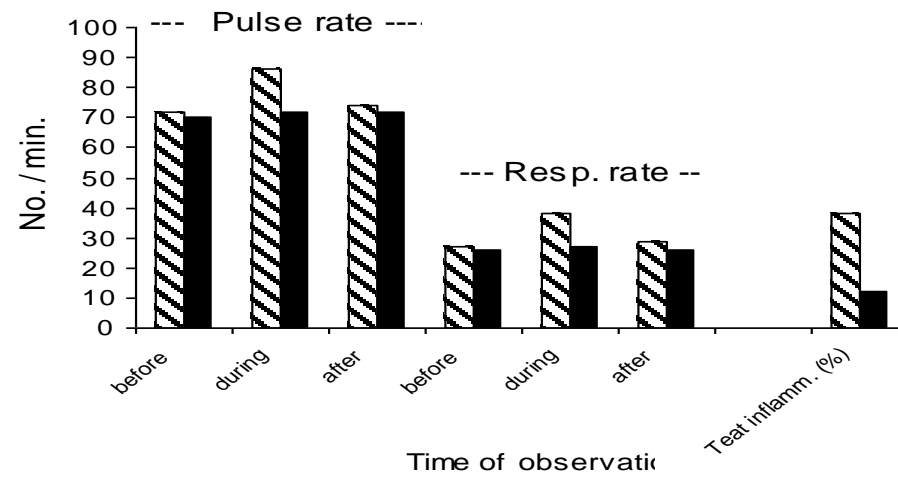

$\mathbf{\nabla}$ Autom atic

- Hand

Fig. (4): - Health status meas urements of cows duri autom atic and hand milking

Table 4: Average serum cortisol level inside byres and milk cortisol level $(\mu \mathrm{g} / 100 \mathrm{ml})$ during automatic and hand milking of cows

\begin{tabular}{lccc}
\hline \multicolumn{1}{c}{ Type of milking } & Automatic & Hand & "P" Value \\
\hline Serum cortisol & $0.68 \pm 0.01$ & $0.61 \pm 0.01$ & NS \\
Milk cortisol & $1.67 \pm 0.01$ & $0.63 \pm 0.01$ & $<0.01$ \\
\hline
\end{tabular}

NS = Non-significant 


\section{DISCUSSION}

\section{I-Behavioral observations:-}

The data represented in Table (1) showed the effect of method of milking, either automatic or hand, on the incidence of the studied behavioral indicators of strerss of the milked cows inside their byres during out of milking time. These data indicated that, the method of milking had no significant effect on these behaviors. The incidence of step behavior, kick behavior, scraping, pawing and lip licking among the experimented cows was 0 for all, either during automatic or hand milking. However, the incidence of bellowing among the experimented cows was $5 \%$, for both automatic and hand milking.

In the same time, Table (2) and Figures $(1,2 \& 3)$ showed the effect of method of milking, either automatic or hand, on the studied behavioral indicators of stress of the milked cows during their milking inside parlours. These data indicated that, the method of milking had a significant effect on the incidence of these behaviors inside parlours during milking $(\mathrm{P}<0.01)$.

With regard to step behavior, the obtained data showed that, the incidence of this behavior during udder preparation, main milking and final milking was 3.4, 7.9, 4.8 No. / head following automatic milking. At the same time, the incidence of this behavior was 0.6, 1.2 and 0.9 No. / head following hand milking, respectively.

In relation to kick behavior, the obtained data also showed that, the incidence of this behavior during udder preparation, main milking and final milking was $1.8,8.1,6.8$ No. / head following automatic milking, however, it was $0.4,2.2$ and 1.9 No. / head following hand milking, respectively.

Moreover, the obtained data illustrated that, the incidence of bellowing behavior among the experimented cows during udder preparation, main milking and final milking was 30,60, 50\% following automatic milking, however, it was 5, 10 and 5\% following hand milking, respectively.

With regard to scrapping behavior, the obtained data also illustrated that, the incidence of this behavior during udder preparation, main milking and final milking was 20,30, 30\% following automatic milking, however, it was $0 \%$ during any stage of hand milking.

In relation to pawing behavior, the obtained data demonstrated that, the incidence of this behavior during udder preparation, main milking and final milking was 20,40, 20\% following automatic milking, however, it was $0 \%$ during any stage of hand milking. 
The obtained data also indicated that, the incidence of lip licking behavior among the experimented cows during udder preparation, main milking and final milking was 10, 40,30\% following automatic milking, however, it was 0,10 and $10 \%$ following hand milking, respectively.

In general, the previously mentioned data indicated that, on contrast to hand milking which followed by low incidences of step behavior, kick behaviors, bellowing, lip licking and no incidence of scraping and pawing behaviors, automatic milking of dairy cows was accompanied with a significant increase in the incidences of these behaviors during any of the milking steps.

Changes in the behavior of dairy cows were also found in other studies with automatic milking systems (Kremer and Ordolff, 1992; Uetake et al., 1997; Ketelaar-de Lauwere et al., 1998 and Wenzel et al., 2003). There is a connection between these behaviors and the cow's character. Metz-Stefanowska et al. (1992) and Prescott et al. (1998) indicated that, nervous and anxious animals demonstrate these behaviors more often. Expressing these behaviors during any step of the automatic milking indicated that, cows milked with automatic milking system were more nervous and so, more stressed than those milked handy. Another probable cause of these increased behaviors during automatic milking of cows could be the long period of waiting with several agonistic interactions in front of the milking stall, a factor that may be reflected with a negative experience for those cows and lead to more anxiety before next visits with subsequent changes in their character and behavior (Ketelaar-de Lauwere et al., 1996).

\section{II- Health status: -}

The comparative evaluation of the average pulse rate, respiratory rate as well as the percentage of teat inflammation of the experimented dairy cows that milked either automatically or hand revealed some obvious statistically significant differences as shown in Table $3(\mathrm{p}<0.01)$.

With regard to pulse rate, the obtained data which assimilated on Figure (4) showed that, average pulse rate before, during and after milking of the experimented animals was 72, 86, 74 and 70, 72, 72 No. / minute following automatic and hand milking, respectively. At the same time, the average respiratory rate of the same animals was 27, 38, 29 and 26, 27, 26 No. / minute following automatic and hand milking, respectively. These data indicated that, both of pulse and respiratory rates were significantly increased during automatic milking than did hand one, while they returned to its normal levels directly after milking. The aforementioned data illustrated that, cows were more excited during 
automatic milking than hand one which indicated by the significant increase in their pulse and respiratory rates. It has been previously shown that a cow's pulse and respiratory rates increased in response to the machine milking (Royle et al., 1992). This increase in pulse and respiratory rates may be due to the expectation of pain from the cups of the milking machines (Lay et al., 1992 and Robert et al., 1997). Another cause of this increase in pulse and respiratory rates may be the effect of the automatic milking on the character of the experimented cows as it rendered it more nervous during milking (Hopster et al., 1998 and Wenzel et al., 2003).

With regard to teat inflammation, Table (3) and also Figure (4) showed that, method of milking had a significant effect on the incidence of teat inflammation among the experimented animals $(\mathrm{p}<0.01)$. The obtained data indicated that, the incidence of teat inflammation among the experimented animals that milked automatically or hand was 38 and $12 \%$, respectively. These data indicated that, the incidence of teat inflammation was significantly increased following automatic milking. The increased incidence of teat inflammation among dairy cows that milked automatically may be related to the effect of the vacuum of the milking machine as well as teat cups on the udder and teats of the milked animals (Blood \& Radostits, 1990 and Wenzel et al., 2003).

\section{III- Serum and milk cortisol concentration:-}

The data illustrated in Table (4) and assimilated on Figure (5) showed the effect of method of milking on the cortisol level of the serum and milk of cows during out of milking hours inside their byres and during milking inside parlours, respectively.

In-byres serum cortisol level of cows that either milked automatically or handy was 0.68 and $0.61 \mu \mathrm{g} / 100 \mathrm{ml}$, respectively. At the same time, in-parlour milk cortisol level of cows during their automatic and hand milking was 1.67 and $0.63 \mu \mathrm{g} / 100 \mathrm{ml}$, respectively. This finding indicated that, the in-byre serum cortisol level was insignificantly affected with the method of milking, however, in-parlour milk cortisol level was significantly increased during automatic milking than handy one $(\mathrm{P}<0.01)$.

There is a positive correlation between plasma and milk cortisol. In general, milking induces an increase in peripheral cortisol (Fox et al., 1981; Gorewit et al., 1992 and Samuelsson et al., 1996). Cows milked in the automatic milking system showed a higher level of cortisol than the hand milked ones, which could be interpreted as a more intense stress reaction. This significant increase in the milk cortisol level during 
automatic milking of cows indicated an incidence of a powerful acute stress during milking which was followed by a more outpouring of ACTH which intern caused the adrenal cortex to increase its secretion of glucocorticoids including cortisol with subsequent increase of its level in the blood of stressed cows and finally excreted in their milk (McDonald, 1969; Burchfield et al., 1980 and Kindahl et al., 2002).

\section{CONCLUSION}

In conclusion, although auto milking is a very important matter in increasing the milk yield, it seems to indeed affect the behavioral and physiological response as well as health status of cows during milking. Moreover, this study concluded that, human-animal interaction has known positive effects on cortisol level in the sense of stress reduction, where milking without a stockperson, and therefore without any handling procedures, could be more stressful. This finding recommended that, presence of stockpersons or workers who managed the dairy cows during their auto milking is of great importance to minimize stress and so, decrease the level of cortisol in the collected milk.

\section{REFERENCES}

Blood, D.C. and Henderson, J.A. (1974): Veterinary medicine. $4^{\text {th }}$ Ed., Bailliere-Tindall-London.

Blood, D.C. and Radostitis, O.M. (1990): Veterinary medicine. $7^{\text {th }}$ Ed., UK.

Burchfield, S.R.; Wood, S.C. and Elich, M.S. (1980): Pituitary adrenocortical response to chronic intermittent stress. Physiol. And Behav., 24: 297-302.

Dandliker, W.B. and Feigen, G.A. (1970): Quantification of the antigenantibody reaction by polarization immunochemistry. Immunochemistry, 7: 799-828.

Dandliker, W.B. and Saussure, D.V. (1973): Review article: fluorescent polarization immunoassay. Theory and experimental method. Immunochemistry, 10: 219-227.

Fox, L.; Butler, W.R.; Everett, R.W. and Natzke, R.P. (1981): Effect of adrenocorticotropin on milk and plasma cortisol and prolactin concentrations. J. Dairy Sci., 64: 1794-1803.

Gorewit, R.C.; Svennersten, K.; Butler, W.R. and Uvnäs-Moberg, K. (1992): Endocrine responses in cows milked by hand and machine. J. Dairy Sci., 75: 443-448 
Hemsworth, P.H.; Barnett J.L.; Tilbrook, A.J. and Hansen, C. (1989): The effects of handling by humans at calving and during milking on the behaviour and milk cortisol concentrations of primiparous dairy cows. Appl. Anim. Behav. Sci., 22: 313-326.

Hopster, H.; Van Der Werf, J. and Blokhuis, H. (1998): Side preference of dairy cows in the milking parlour and its effects on behaviour and heart-rate during milking. Appl. Anim. Behav. Sci., 55: 213-229.

Hopster, H.; Van Der Werf, J.; Korte-Bouws, G.; Macuhova, J.; Van Reenen, C.G; Bruckmaier, R.M. and Korte, S.M. (2000): Automatic milking in dairy cows: welfare indicators of Astronaut effectiveness. In: Robotic Milking, Wageningen Pers, Wageningen, NL: 259-266.

Ipema, A.H.; Wierenga, H.K.; Metz, J.; Smits, A.C. and Rtossing, W., (1988): The effects of automated milking and feeding on the production and behaviour of dairy cows. In: Automation of Feeding and Milking: Production, Health, Behaviour and Breeding, Pudoc Scientific Publishers, Wageningen, NL: 11-24.

Ketelaar-de Lauwere, C.C.; Devir, S. and Metz, J.H.M. (1996): The influence of social hierarchy on the time budget of cows and their visits to an automatic milking system. Appl. Anim. Behav. Sci., 49: 199-211.

Ketelaar-de Lauwere, C.C.; Hendriks, J.M.; Metz, H.M. and Schouten, W.G. (1998): Behaviour of dairy cows under free or forced cow traffic in a simulated automatic milking system environment. Appl. Anim. Behav. Sci., 56: 13-28.

Kindahl, H.; Kornmatitsuik, B.; Konigsson, K. and Gustafsson, $H$. (2002): Endocrine changes in late bovine pregnancy with special emphasis on fetal well being. Anim. Endocrinol., 23: 21-328.

Kremer, J.H. and Ordolff, D. (1992): Experiences with continuous robot milking with regard to milk yield, milk composition and behaviour of cows. In: Prospects For Automatic Milking, Pudoc Scientific Publishers, Wageningen, NL: 278-288.

Lay, D.C.; Friend, J.; Grissom, K.K.; Hale, R.L. and Bowers, C.L. (1992): Novel breeding box has variable effects on heart rate and cortisol response of cattle. Appl. Anim. Behav. Sci., 35: $1-10$. 
Little, W.; Collis, K.A.; Gleed, P.T.; Sansom, P.F. and Allen, W.M. (1979): Effect of reduced water intake by lactating dairy cows on behaviour, milk yield and blood composition. Vet. Rec., 106: 547-551.

Marten, P. and Bateson, P. (1988): In Measuring behaviour. Cambridge University Press, Cambridge, pp. 48-69.

McDonalds, L.E. (1969): Veterinary endocrinology and reproduction. 1st Ed., Lea and Febiger, Philadelphia, USA.

Metz-Stefanowska, J.; Huijsmans, P.J.; Hogewerf, P.H.; Ipema, A.H. and Keen, A. (1992): Behaviour of cows before, during and after milking with an automatic milking system. In: Prospects For Automatic Milking, Pudoc Scientific Publishers, Wageningen, NL: 278-288.

Prescott, N.B.; Mottram, T.T. and Webster, A.J. (1998): Effect of food type and location on the attendance to an automatic milking system by dairy cows and the effect of feeding during milking on their behaviour and milking characteristics. Anim. Sci., 67: 183-193.

Robert, S.; Rushen, J. and Farmer, C. (1997): Both energy content and bulk of food affect stereotypic behaviour, heart rate and feeding motivation of female pigs. Appl. Anim. Behav. Sci., 54: 161-171.

Royle, C.; Garnsworthy, P.C.; McArthur, A.J. and Mepham, T.B. (1992):

Effects of frequent milking on heart rate and other physiological variables in dairy cows. In: Prospects For Automatic Milking, Pudoc Scientific Publishers, Wageningen, NL: 237-243.

Samuelsson, B.; Uvnäs-Moberg, K.; Gorewit, R.C. and SvennerstenSjaunja, K. (1996): Profiles of the hormones somatostatin, gastrin, CCK, prolactin, growth hormone and cortisol in dairy cows that are milked and fed separately or milked and fed simultaneously. Livest. Prod. Sci., 46: 49-56.

SAS (1995): Statistical analysis system. User's Guide: Statistics. Version $6,2^{\text {nd }}$ Ed., SAS Inst. Inc., Cary, NC.

Uetake, K.; Hurnik, J.F. and Johnson, L. (1997): Behavioural pattern of

dairy cows milked in a two-stall automatic milking system with a holding area. J. Anim. Sci., 75: 954-958.

Wenzel, C.; Schonrieter-Fischer, S. and Unshelm, J. (2003): Studies on step-kick behavior and stress of cowes during milking in an automatic milking system. Livestock Prod. Sci., 83: 237-246. 
Assiut Vet. Med. J. Vol. 53 No. 114 July 2007 


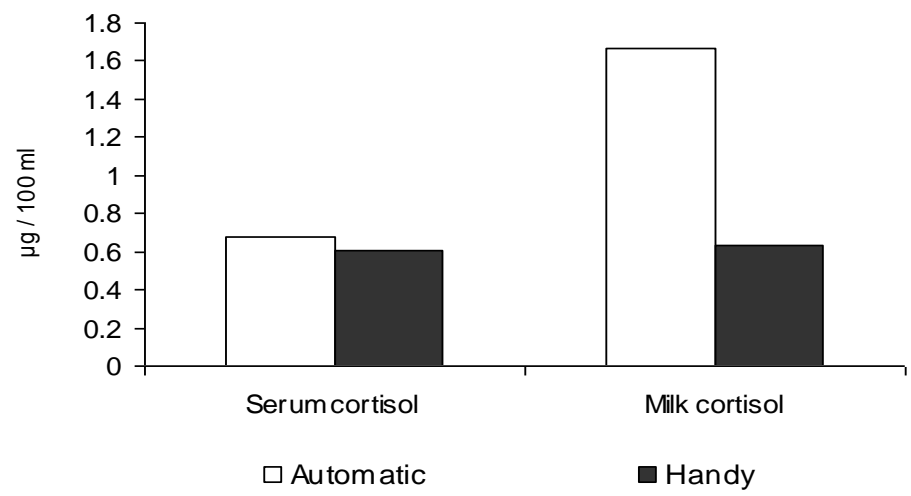

Fig. (5) : - Serum cortisol level inside byres and milk cortis level during milking of cows 